\title{
Serological Investigation on Leptospirosis in Clinically Ailing Goats
}

\author{
Priti D. Vihol ${ }^{1}$, Jignesh M. Patel ${ }^{1}$, Jatin H. Patel ${ }^{2}$, Jeetendra K. Raval ${ }^{3}$, \\ Irsadullakhan H. Kalyani ${ }^{4}$ and Rasesh D. Varia ${ }^{2}$
}

${ }^{1}$ Department of Veterinary Pathology, College of Veterinary Sciences and Animal Husbandry, Navsari Agricultural University, Eru cross road, Navsari-396 450, Gujarat, India.

${ }^{2}$ Department of Veterinary Pharmacology and Toxicology, College of Veterinary Sciences and Animal Husbandry, Navsari Agricultural University, Eru cross road, Navsari-396 450, Gujarat, India

${ }^{3}$ TVCC, College of Veterinary Sciences and Animal Husbandry, Navsari Agricultural University, Eru cross road, Navsari-396 450, Gujarat, India.

${ }^{4}$ Department of Veterinary Microbiology, College of Veterinary Sciences and Animal Husbandry, Navsari Agricultural University, Eru cross road, Navsari-396 450, Gujarat, India

*Corresponding author

\section{A B S T R A C T}

\begin{tabular}{|l|}
\hline K e y w or d s \\
Goats, \\
Leptospirosis, \\
$\begin{array}{l}\text { Serovars, } \\
\text { South Gujarat. }\end{array}$ \\
\hline Article Info \\
\hline $\begin{array}{l}\text { Accepted: } \\
\text { 06 March } 2017 \\
\text { Available Online: } \\
10 \text { April } 2017\end{array}$ \\
\hline
\end{tabular}

Serum samples from 126 clinically ailing goats showing signs like anorexia, fever, oligolactia, mastitis, icteric mucous membranes and abortion from different villages of Navsari, Surat, Tapi and Valsad districts of South Gujarat were examined for antileptospiral antibodies by microscopic agglutination test (MAT) using 17 serovars. Among screened goats, seropositivity was found to be $14.29 \%$. Seroreactivity was noted against serovars Hardjo, Canicola, Pomona, Pyrogenes, Bankinang, Grippotyphosa, Patoc1 and Australis. Female goats showed comparatively higher seropositivity than male goats. Age wise leptospiral seropositivity was found to be higher in goats above 3 years of age. Present result suggests leptospirosis in goats and also indicates circulation of reported serovars in south Gujarat.

\section{Introduction}

Leptospirosis is worldwide zoonotic disease affecting domestic animals, wild animal and human beings. The disease causes economical losses in terms of decreased production performances and reproduction related problems in livestock. In India, leptosporsis in goats has been reported by many earlier workers (Verma et al., 2001; Sivaseelan et al., 2003; Balakrishnan et al., 2008; Meenakshisundaram and Chellapandian, 2010, Vihol et al., 2016). The disease occurs subclinically in goats and most often goes undiagnosed in field. It causes impaired fertility, neonatal deaths, abortions and decreased milk production in goats (Ellis, 1994). Infected goats develop chronic renal infection, become carrier of leptospires and disseminate bacteria through urine and contaminates the surroundings (Lilenbaum et $a l .$, 2009). In India, studies on leptospirosis in clinically ailing goats are limited. So the present study was undertaken to know the 
leptospiral seroprevalence and serovars distribution among clinically ailing goats in south Gujarat.

\section{Materials and Methods}

A total of 126 serum samples were collected from clinically ailing goats from different villages of Navsari, Surat, Tapi and Valsad districts of South Gujarat. These animals showed clinical signs like anorexia, fever, agalactia/oligolactia, mastitis, icteric mucous membranes and abortion. At the same visit of sample collection, age and sex of animals were also noted.

Whole blood samples were collected from individual animal by jugular vein puncture directly in sterile $9.0 \mathrm{ml}$ plain vacutainers. Samples were transported under cold chain system to our pathology laboratory. To obtain serum whole blood was kept in slanting position in $9.0 \mathrm{ml}$ plain vacutainers until serum was extracted out. The $9.0 \mathrm{ml}$ plain vacutainers were centrifuged at $7000 \mathrm{rpm}$ for 10 minutes, if needed. The straw coloured serum was collected into $1.5 \mathrm{ml}$ sterile cryo vials and stored at $-20{ }^{\circ} \mathrm{C}$ for MAT.

\section{Microscopic Agglutination Test (MAT)}

Serum samples were tested for antibodies against live antigens of Leptospira sp. (serovars Pyrogenes, Australis, Bankinang, Grippotyphosa, Patoc-1, Pomona, Icterohaemorrhagiae, Hebdomadis, Canicola, Hardjo, Bellum, Bataviae, Tarassovi, Shermani, Kaup, Hurstbridge and Javanica) by MAT at Leptospirosis Reference Laboratory, Government Medical College, Surat (Vijayachari et al., 2001) and/or National Institute of Veterinary Epidemiology and Disease Informatics (NIVEDI), Indian Council of Agricultural Research, formerly Project Directorate on Animal Disease Monitoring and Surveillance (PD-ADMAS),
Hebbal, Bengaluru using standard procedure (Faine, 1982; WHO, 2013).

\section{Statistical analysis}

For statistical analysis, Chi-square test was used and considered to be significant at $<0.05$. Data were analysed using Web Argi Stat Package (WASP) software developed by Jangam and Wadekar, Indian Council of Agricultural Research (ICAR), Goa, India (Jangam and Wadekar, 2012).

\section{Results and Discussion}

Out of total 126 serum samples screened from clinically ailing goats, antileptospiral antibodies were detected in 18 samples indicating $14.29 \%$ seropositivity. Among seropositive goats history of abortion was recorded in maximum number of cases $(23.08$ $\%)$ followed by icteric mucous membranes (21.05\%), oligolactia/agalactia (14.29\%), fever $(13.33 \%)$, mastitis $(10.00 \%)$ and anorexia $(3.57 \%)$ in different combinations (Table 1). Our findings were in agreement with the earlier observations made in goats (Faine et al., 2000; Lilenbaum et al., 2007; Lilenbaum et al., 2008). Balakrishnan (2012) reported higher seropositivity in clinically ailing goats. Reproductive problems seen in goats might be due to the localization of leptospires in reproductive tract/uterus (Dehkordi et al., 2011) which impairs fertility. In an endemic scenario as observed in this study subclinical expressions are common and play an important role in the epidemiology of the disease. In addition further, the variations in clinical expression might be due to the stage of the infection, various contributing factors and susceptibility index of individual animals to the infection.

Serovars reported from clinically ailing goats were Hardjo, Canicola, Pomona, Pyrogenes, Bankinang, Grippotyphosa, Patoc1 and 
Australis (Table 2). Serovars Pomona, Hardjo and Canicola were reported with abortion cases and serovars Pyrogenes and Hardjo were reported from mastitis and oligolactia cases respectively. Serovars Pyrogenes, Pomona, Canicola, Bankinang, Grippotyphosa, Patoc1 and Australis were reported in animals with icteric mucous membranes. The study revealed presence of more than one serovars in goats with abortion, fever or icteric mucous membranes. The present findings were in agreement with the observations made in clinically ailing goats from India in past (Tripathy et al., 1985; Balakrishnan, 2012). Balakrishnan (2012) reported 5 serovars namely Hardjo, Hebdomadis, Australis, Icterohaemorrhagiae and Pomona in seropositive goats with clinical symptoms. On the same line Tripathy et al., (1985) reported involvement of serovars Pomona and Hardjo in seropositive goats with mild clinical signs like pyrexia and reduction in milk yield. Many workers have reported involvement of serovar Hardjo (Ellis et al., 1986; Faine et al., 2000), serovar Pomona (Leon-Vizcaino et al., 1987) in abortion cases. It is noteworthy report involvement of serovar Pomona as predominant one in goats with abortion.
Age-wise highest prevalence was noted in goats above 3 years of age $(7 / 47,14.90 \%)$ followed by $1-3$ years of age $(10 / 68,14.71 \%)$ and below 1 year age $(1 / 11,9.09 \%)$ (Table 3 ). Thus it may be noted that higher age (3 years and above) in goats favors the occurrence of leptospiral expressions. Beside this it indicates that among clinically ailing seropositive animals the prevalence of leptospirosis was directly proportional to the age of animals signifying higher chances of frequent exposure as the animal ages might be responsible and supported the views of Talebkhan et al., (2003), Hassanpour et al., (2008) and Balakrishnan (2012).

In present study, clinical expressions were seen in more number of female goats $(18.31$ $\%)$ in comparison to male goats $(9.09 \%)$ (Table 4) and supported the observation of earlier workers (Agunloye et al., 1997; Faine et al., 2000 and Lilenbaum et al., 2007; Abiayi et al., 2011). Contrary to this, Agunloye (2002) and Balakrishnan (2012) reported higher prevalence in male goats (bucks) than female goats does. Agunloye (2002) reported that there is no reliable evidence that the gender of animals can influence the prevalence rate of the disease.

Table.1 Details Leptospiral seropositivity in clinically ailing goats

\begin{tabular}{|c|l|c|c|}
\hline $\begin{array}{c}\text { Sr. } \\
\text { No. }\end{array}$ & \multicolumn{1}{|c|}{ Clinical signs } & $\begin{array}{c}\text { Total no. of } \\
\text { cases }\end{array}$ & No. of seropositive animals \\
\hline 1. & Abortion & 13 & $3(23.08 \%)$ \\
\hline 2. & Anorexia & 28 & $1(3.57 \%)$ \\
\hline 3. & Fever & 30 & $4(13.33 \%)$ \\
\hline 4. & Oligolactia & 7 & $1(14.29 \%)$ \\
\hline 5. & Mastitis & 10 & $1(10.00 \%)$ \\
\hline 6. & Icteric mucous membranes & 38 & $8(21.05 \%)$ \\
\hline & Total & 126 & $18(14.29 \%)$ \\
\hline
\end{tabular}


Table.2 Details of serovars reported in clinically ailing goats

\begin{tabular}{|c|c|c|c|}
\hline Sr. No. & Clinical signs & No. of cases (Per cent) & Serovars reacted \\
\hline \multirow{2}{*}{1.} & \multirow{2}{*}{ Abortion } & $1(5.56 \%)$ & Hardjo and Canicola \\
\hline & & $2(11.11 \%)$ & Pomona \\
\hline 2. & Anorexia & $1(5.56 \%)$ & Hardjo \\
\hline \multirow[b]{2}{*}{3.} & \multirow[b]{2}{*}{ Fever } & $3(16.67 \%)$ & Pyrogenes \\
\hline & & $1(5.56 \%)$ & $\begin{array}{l}\text { Bankinang, Grippotyphosa } \\
\text { and Patoc1 }\end{array}$ \\
\hline 4. & Oligolactia & $1(5.56 \%)$ & Pyrogenes \\
\hline 5. & Mastitis & $1(5.56 \%)$ & Hardjo \\
\hline \multirow{6}{*}{6.} & \multirow{6}{*}{$\begin{array}{l}\text { Icteric } \\
\text { mucous } \\
\text { membranes }\end{array}$} & $2(11.11 \%)$ & Pyrogenes \\
\hline & & $1(5.56 \%)$ & Australis \\
\hline & & $2(11.11 \%)$ & Pomona \\
\hline & & $1(5.56 \%)$ & Pyrogenes and Bankinang \\
\hline & & $1(5.56 \%)$ & Bankinang, Patoc 1 and Pomona \\
\hline & & $1(5.56 \%)$ & $\begin{array}{l}\text { Grippotyphosa, Patoc1 and } \\
\text { Canicola }\end{array}$ \\
\hline
\end{tabular}

Table.3 Agewise details of seropositivity in clinically ailing goats

\begin{tabular}{|c|c|c|c|}
\hline Sr. No. & Particulars & Total no. of cases & No. of seropositive animals \\
\hline 1. & $<1$ year & 11 & $1(9.09 \%)$ \\
\hline 2. & $1-3$ years & 68 & $10(14.71 \%)$ \\
\hline 3. & $>3$ years & 47 & $7(14.90 \%)$ \\
\hline \multicolumn{2}{|r|}{} & 126 & $18(14.29 \%)$ \\
\hline & Total & \multicolumn{2}{c|}{$\chi^{2}=0.264^{\mathrm{NS}}$} \\
\hline
\end{tabular}

Note: ${ }^{\mathrm{NS}}$-Non significant at $\mathrm{P}<0.05$

Table.4 Sexwise details of seropositivity in clinically ailing goats

\begin{tabular}{|c|c|c|c|}
\hline Sr. No. & Particulars & Total no. of cases & No. of seropositive animals \\
\hline 1. & Male & 55 & $5(9.09 \%)$ \\
\hline 2. & Female & 71 & $13(18.31 \%)$ \\
\hline \multicolumn{2}{|r|}{ Total } & 126 & $18(14.29 \%)$ \\
\hline & \multicolumn{2}{c}{} & $\chi^{2}=2.150^{\mathrm{NS}}$ \\
\hline
\end{tabular}

Note: ${ }^{\text {NS }}$-Non significant at $\mathrm{P}<0.05$

In conclusion, seropositivity in screened goats in south Gujarat indicates contaminated environment of the region and threat to other animals and humans. The study indicated circulation of various serovars. Leptospirosis is reported as cause of reproductive losses in animals and it should be considered when investigating any reproductive problems where infection is suspected. Further epidemiological studies including different 
animals and humans should be carried out in the south Gujarat, to combat this zoonotic disease.

\section{Acknowledgements}

Authors are very thankful to Dr. Sumaiya Mulla, Professor, Head and In-charge Leptospirosis Reference Laboratory at Government Medical College, Surat and Dr. A. R. Rehman, Director, National Institute of Veterinary Epidemiology and Disease Informatics (NIVEDI), Indian Council of Agricultural Research, Hebbal, Bengaluru for technical support. We are also thankful to Dr. N. H. Kelawala, Dean and Principal, Vanbandhu College of Veterinary Science and Animal Husbandry, Navsari Agricultural College, Navsari for financial assistance.

\section{References}

Abiayi, E.A., Ajani, O.G., Micheal, J.I., Kumbish, P.R., Odugbo, M., Inabo, H.I. and Okewole, P. 2011. Serological evidence of leptospiral infection in sheep and goat in Benue, Nigeria. Book of abstract, of the $48^{\text {th }}$ annual NVMA congress, Kwara State.

Agunloye, C.A., Oyeyemi, M.O., Akusu, M.O., Ajala, O.O. and Agbede, S.A. 1997. Clinical and serological diagnosis of leptospirosis in aborting West African Dwarf goats. Bull. Anim. Health. Prod. Afr., 45: 5-8.

Agunloye, C.A. 2002. Leptospiral agglutinating antibodies in sheep and goats in South-West Nigeria. Israel J. Vet. Med., 57(2): 156-158.

Balakrishnan, G. 2012. Seroprevalence of leptospirosis in goats in Tamil Nadu. Tamilnadu J. Vet. Anim. Sci., 8(3): 138144.

Balakrishnan, G., Govindarajan, R., Meenambigai, T. V., Vajiravelu J. and Murali Manohar, B. 2008.
Seroprevalence of Leptospirosis among domestic animals in Andra Pradesh. Indian Vet. J., 85: 551-552.

Dehkordi, J.A., Shahbazkia, H.R. and Ronagh, N. 2011. Evaluation of pathogenic serovars of Leptospira interrogans in dairy cattle herds of Shahrekord by PCR. Iran. J. Microbiol., 3(3): 135-139.

Ellis, W.A. 1994. Leptospirosis as a cause of reproductive failure. Vet. Clin. North Am. Food Anim. Pract., 10(3): 463-478.

Ellis, W.A., Songer, J.G., Montgomery, J. and Cassels, J.A. 1986. Prevalence of Leptospira interrogans serovar Hardjo in the genital and urinary tracts of nonpregnant cattle. Vet. Rec., 118: 11-13.

Faine, S. 1982. In: Guidelines for the control of leptospirosis, Geneva, WHO, 67.

Faine, S., Adler, B., Bolin, C. and Perolat, P. 2000. Leptospira and leptospirosis. $2^{\text {nd }}$ ed. Med. Sci., Melbourne, Australia.

Hassanpour, A., Fartashvand, M., Abdolahpour, G., Moghadam, G., Nadalian, M.G. and Satari, S. 2008. Determination of the serological infection to leptospiral infection in Tabriz dairy cattle herds. Pajouhesh Sazandeghi, 74: 67-77.

Leon-Vizcaino, L., Hermoso de Mendoza, M. and Garrido, F. 1987. Incidence of abortions caused by leptospirosis in sheep and goats in Spain. Comp. Immunol. Microbiol. Infect. Dis., 10(2): 149-53.

Lilenbaum, W., De Souza, G.N., Ristow, P., Moreira, M.C., Fráguas, S., Cardoso Vda, S. and Oelemann, W.M. 2007. A serological study on Brucella abortus, caprine arthritis-encephalitis virus and Leptospira in dairy goats in Rio de Janeiro, Brazil. Vet. J., 173(2): 408-412.

Lilenbaum, W., Varges, R., Branda, F.Z., Cortez, A., De souza, S.O., Branda, P. E., Richtzenhain, L.J. and Vasconcellos, S.A. 2008. Detection of Leptospira spp. 
in semen and vaginal fluids of goats and sheep by polymerase chain reaction. Theriogenol., 69: 837-842.

Lilenbaum, W., Varges, R., Ristow, P., Cortez, A., De souza, S.O., Richtzenhain, L.J. and Vasconcellos, S.A. 2009. Identification of Leptospira spp. carriers among seroreactive goats and sheep by polymerase chain reaction. Res. Vet. Sci., 87: 16-19.

Meenakshisundaram, A. and Chellapandian, M. 2010. Sero-prevalence of leptospirosis in small ruminants in Virudhunagar district of Tamil Nadu. Tamil Nadu J. Vet. Anim. Sci., 6: 136137.

Sivaseelan, S., Uma Rani, R. and Kathiresan, D. 2003. Sero-prevalence of leptospirosis in sheep and goats in Madurai District-Tamil Nadu. Indian Vet. J., 80: 375-376.

Talebkhan, G.M., Vandeussefi, J., Familghadakchi, H. and Nowrouzian, I. 2003. A seroepidemiological survey of leptospiral infection in dairy cattle herds and their employees in Mashhad suburb of Iran. J. Vet. Med. Tehran Univ., 58: 89-94.
Tripathy, D.N., Hanson, L.E., Mansfield, M.E. and Thilsted, J.P. 1985. Experimental infection of lactating goats with Leptospira interrogans serovars Pomona and Hardjo. Am. J. Vet. Res., 46(12): 2512-2514.

Verma, A., Rai, R.B., Balakrishnan, P., Gupta, A. and Naveen, K.A. 2001. Seroprevalence of leptospirosis in animals of Andaman and Nicobar islands. Indian Vet. J., 78: 936-937.

Vihol, P.D., Patel, J.M., Patel, J.H., Prasad, M.C., Kalyani, I.H. and Brahmkshtri, B.P. 2016 Caprine leptospirosis: Hematobiochemical and urinalyses studies, Vet. World, 9(3): 337-341.

Vijayachari, P., Sugunan, A.P., Umapathi, T. and Sehgal, S.C. 2001. Evaluation of dark ground microscopy as a rapid diagnostic procedure in leptospirosis. Indian J. Med. Res., 114: 54-58.

World Organization for Animal Health (Office International des Épizooties OIE). 2013. Chapter 2.1.9 In: Manual of Diagnostic Tests and Vaccines for Terrestrial Animals. OIE, Paris, pp. 251-264.

\section{How to cite this article:}

Priti D. Vihol, Jignesh M. Patel, Jatin H. Patel, Jeetendra K. Raval, Irsadullakhan H. Kalyani and Rasesh D. Varia. 2017. Serological Investigation on Leptospirosis in Clinically Ailing Goats. Int.J.Curr.Microbiol.App.Sci. 6(4): 845-850.

doi: https://doi.org/10.20546/ijcmas.2017.604.105 